\title{
STANDARDISATION IN ULTRASONOGRAPHY: PRINCIPLE AND DIAGNOSTIC SIGNIFICANCE
}

\author{
Zuzana Hlinomazová ${ }^{1}$, Ivo Hrazdira ${ }^{2}$ \\ Masaryk University of Brno, Faculty of Medicine, Czech Republic: University Hospital Bohunice, Eye Clinic ${ }^{1}$; St. Anna \\ University Hospital, Clinic of Imaging Methods ${ }^{2}$

\begin{abstract}
Summary: Disadvantage of ultrasonography is its dependence on subjective assessment of displayed images. The way how to minimize both intraobserver and interobserver differences is creation of standard conditions for examination including a quantitative approach to evaluation of tissue reflectivity. The oldest mode of standardisation is standardised A- scan, used in ophthalmology. It enables differentiation of echoes, reflected from different ocular structures and is helpful in assessment of extraocular muscle thickness. Standardisation of B- scan depends on the type of diagnostic device and is based on quantification of image echogenicity. In our study reference values of grey-level histogram were established for some thyroid diseases using standard setting of imaging parameters. Results indicate that both standardised A- and B- scan should be helpful in differential diagnostics.
\end{abstract}

Key words: Standardised echography; Ultrasonography; A- scan; B- scan; Echogenicity

\section{Introduction}

Evaluation of sonograms is based on subjective assessment of displayed image. Unequal values of image parameters (brightness, contrast, structure, homogeneity) may lead to intraobserver and mainly interobserver differences in image interpretation. Many attempts struggled to overcome this disadvantage by standardising the conditions of examination. Standardisation allows every examiner to obtain the same echogram when examining the same type of tissue and to achieve repeatable and comparable results. Standardisation is relatively easy in one-dimensional A-scan, depending mainly on the form of tissue- echo amplification. The standardised A- scan is hitherto used in ophthalmology. Standardisation of B- scan is more complicated, because the image quality depends on numerous parameters. The aim of this study was to accentuate the parameters of ultrasound image standardisation and assess its clinical significance.

\section{Standardised A- scan}

This mode is used in ophthalmology only. Eye tissues in comparison to other human tissues have relative low attenuation. This enables application of high frequencies $(10-20 \mathrm{MHz})$ and achievement of higher axial and lateral resolution. Besides of 2D and 3D imaging ophthalmology as a single medical branch exploits also A scan, firstly in the standardised form. This consists in usage of a special „S“shaped amplification curve enabling the optimal displaying of tissue echo. The optimal dynamic range for imaging of eye structures is $65 \mathrm{~dB}$. Increasing this value by $6 \mathrm{~dB}$ is necessary for imaging of very tiny opacities in aqueous humour. Lowering this value by $24 \mathrm{~dB}$ enables to imagine very low echoic structures (3). The term of standardised A- scan have been introduced in ophthalmologic examination by Ossoinig $(10,11)$. „S“amplification is for displaying of ocular echoes more advantageous than linear or logarithmic ones. Examination in standardised A- scan involves a special ultrasound device. The first ultrasound machine for standardised A- scan was 7200MA (Kretztechnik) with an $8 \mathrm{MHz}$ transducer, one of its successor is Ophtascan $\mathrm{S}$ (Biophysics Medical) using a $10 \mathrm{MHz}$ probe. Actually the standardised A- scan is combined with the B- scan. The twodimensional B- scan renders synoptic images of the eye and orbit and determines planes for detailed examination $(1,3)$. Standardised A- scan is used preferably for reflectivity assessment enabling differentiation of various ocular lesions (retinal detachment, tumour, foreign body). Particularly useful is standardized A- scan in examination of extraocular muscles $(2,9,12)$ and of optic nerve (5). In evaluation of extraocular muscles results of measurement with ultrasound are comparable to those with MRI (2).

Figure 1 shows standardised A- scan of a physiological internal direct muscle. Fig. 2 represents a standardised A- scan of a malignant melanoma of uvea. Figures 3 and 4 


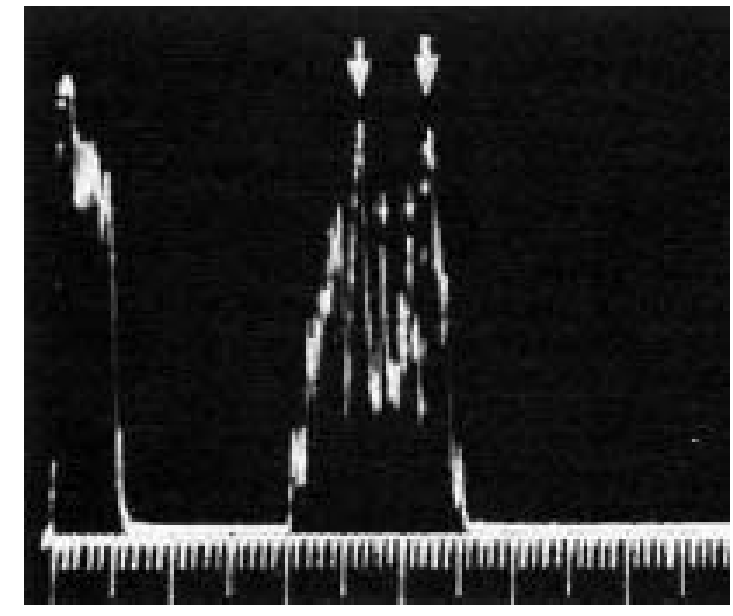

Fig. 1: Standardised A- scan of an oculomotor muscle (great arrows). Small arrows denote the reflectivity of real muscular tissue - physiological state.

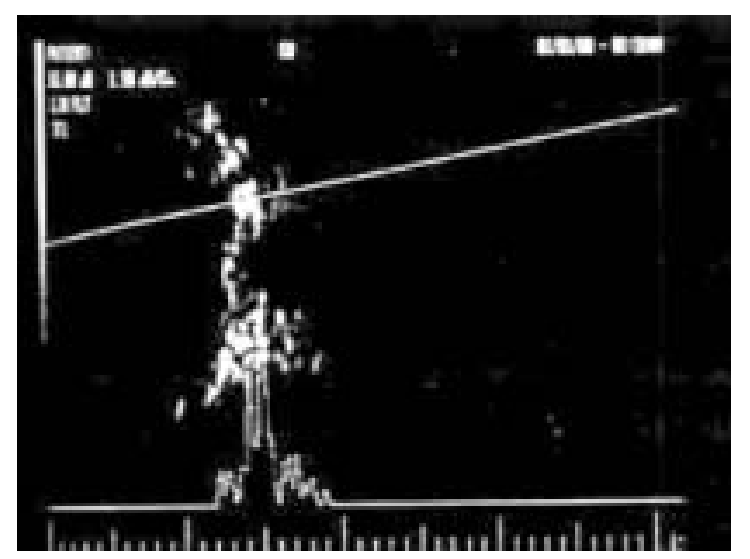

Fig. 3: A- and B- scan of a normal orbit.

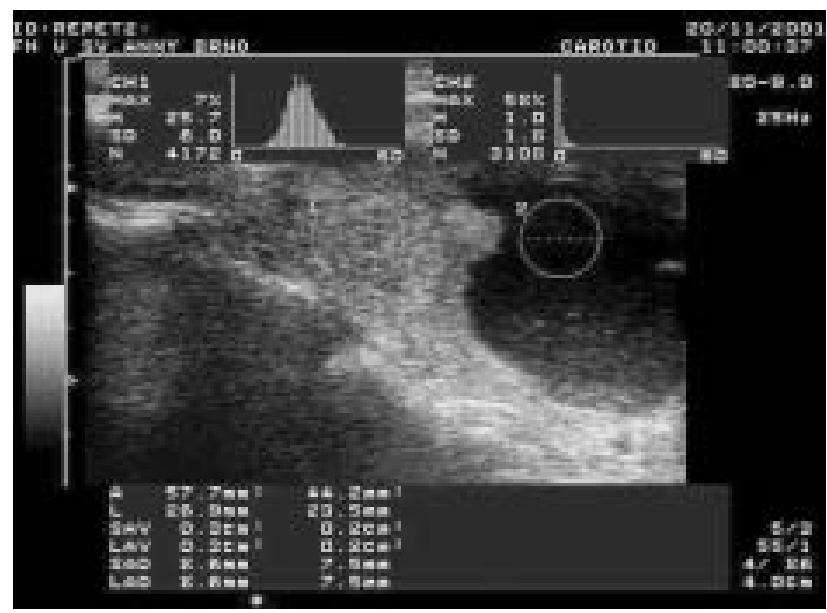

Fig. 5: Grey-level histogram of a thyroid cyst in comparison to a normal thyroid tissue.

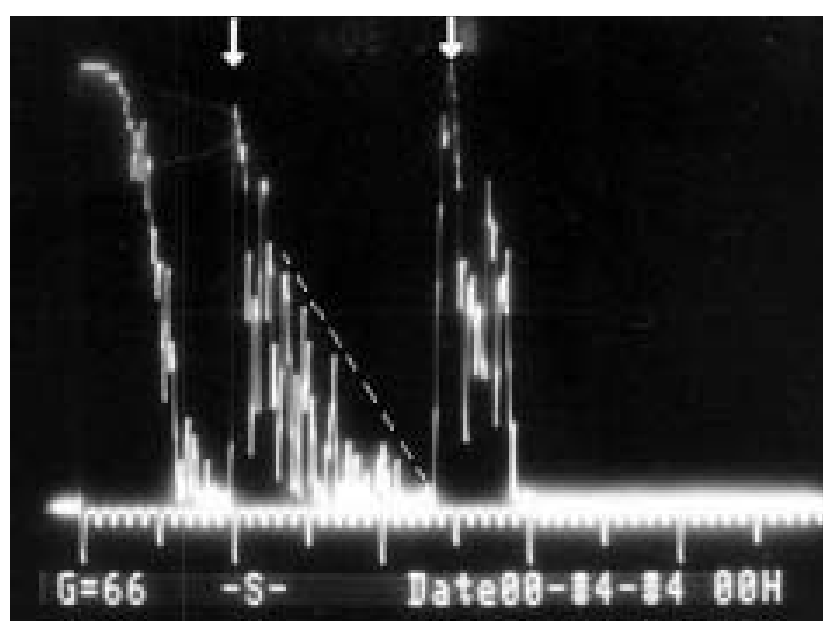

Fig. 2: Standardised A- scan of a malignant melanoma of uvea (arrows). Middle reflectivity with pronounced attenuation (---).

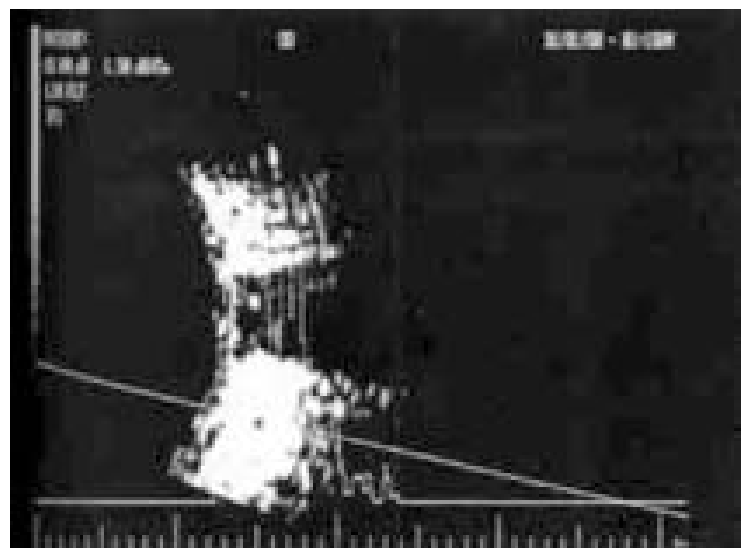

Fig. 4: A-and B- scan of an orbit with higher reflective orbital fat.

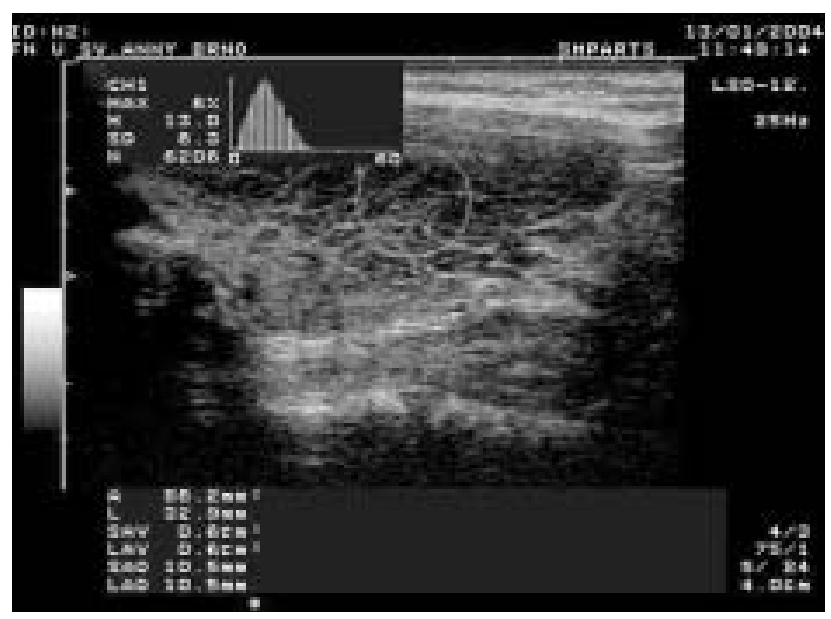

Fig. 6: Grey-level histogram of Hashimoto’s thyroiditis. 
demonstrate superposed A- and B- scan of the orbit with normal and increased reflectivity of orbital fat.

\section{Standardised B- scan}

B- scan is actually used as a common imaging method for examination in many branches of medicine, including ophthalmology. Its advantage is a rapid topographic and structural orientation in the examined region. In distinction to standardised A- scan based on a single echo imaging, the B- scan image is formed by summation of multiple echoes in the given plane and standardization covers several parameters such as brightness, contrast, structure and homogeneity. For standardisation purpose the application of statistical methods is essential. The quantitative approach is based on texture analysis. A simple, but most frequently used method is the assessment of echogram by means of grey-level histograms. The echogram texture is characterised by mean grey value of calculated pixels, its standard deviation and graphical representation of grey level. However, these techniques do not offer the possibility of assessing the relationship between neighbouring pixels. The method is appropriate especially for distinguishing regions with different echogenicity and homogeneity, and was applied mainly in examination of thyroid $(4,8)$. Fig. 5 represents grey-scale histograms of 2 regions of the thyroid gland with different echogenicity and fig. 6 echogram of the same organ with completely inhomogeneous structure.

\section{Clinical benefit}

Together with the technical development of ultrasound diagnostic devices their resolving acuity improves. New machines exploiting computer technology are equipped with new imaging modalities enabling better imaging of tissue echoes.

All attempts for standardisation in ultrasonography are connected with several problems:

1. Adjustment of standard conditions is limited to device used.

2. Standardisation requires great examiner's experience.

3. Setting up of reference values needs application of statistical methods.

The main clinical significance of standardised A- scan consists in differential diagnostics of ocular and orbital tumours, retinal detachment and foreign bodies' identification. However, the correct assessment of A- scan images involves great experience, and therefore the A- scan in the last time should be replaced by new modalities of B- scan with special transducers operating at high frequencies.

The standardised B- scan is based on statistical processing of ultrasound image texture. As an example of this procedure the application of grey-level histogram for echogenicity assessment of thyroid lesions may serve. For this study the ultrasound machine Toshiba Powervision 6000 with a linear $12 \mathrm{MHz}$ transducer at a dynamic range of 84
dB was used. Results of statistical analysis of 200 grey-level histograms of 80 patients are presented in table 1 .

Differences in echogenicity between normal thyroid tissue and various thyroid lesions were highly statistically significant ( $p>0.01$ ). However, we do not confirm literature data indicating that grey-level histograms may be helpful in differentiation between benign and malignant lesions. (6). In our group of patients these differences were not statistically significant. Distinguishing between benign and malignant lesions requires application of more sophisticated statistical methods. We do not agree with the findings that the level of echogenicity may influence the width of histogram (7). In our opinion the width of histogram is function of tissue homogeneity.

Tab. 1: Standardised grey-level values for different thyroid diseases.

\begin{tabular}{|l|c|}
\hline Normal thyroid (25) & $22.6(18.5-26.7)$ \\
Mean grey-level & 4.2 \\
SD & $18.5(15.4-19.8)$ \\
\hline Adenoma (20) & 5.3 \\
Mean grey-level & \\
SD & $17.3(13.6-20.1)$ \\
\hline Carcinoma (15) & 5.2 \\
Mean grey-level & \\
SD & $13.3(9.3-16.4)$ \\
\hline Hashimoto (20) & 5.6 \\
Mean grey-level & \\
SD & \\
\hline
\end{tabular}

\section{Conclusion}

Standardisation of A- and B- scan ultrasonography helps in establishing constant parameters for examination. This leads to reduction of subjective differences in image assessment and thus to improvement of diagnostic accuracy.

\section{References}

1. Byrne SF. Standardized echography of the eye and orbit. Neuroradiology 1986;28:618-40.

2. Demer JL, Kerman BM. Comparison of standardized echography with magnetic resonance Imaging to measure extraocular muscle size. Am J Ophthalmol 1994;118:351-61.

3. Hlinomazová Z. Místo a význam ultrasonografie v diagnostice endokrinních orbitopatií. Dissertation. Faculty of Medicine, Hradec Králové, 1999:108pp.

4. Hrazdira I. Mohou histogramy šedi přispět k přesnější interpretaci ultrazvukových obrazů? Čes Radiol 2003;57:72-4.

5. Haritoglou C, Herzum H, Ehrt O, Ossoinig KC, Kampik A. Echographic differential diagnosis of optic nerve widening. Ophthalmologe 2002;99:559-65.

6. Kitaoka F, Sakai H, Kurda $\mathrm{Y}$ et al. Internal echo histogram examination has a role in diatinguishing malignant tumors from benign masses in the brest. Clin Imaging 2001;25:151-3

7. Maeda K, Utsu M, Kihaile PE. Quantification of sonographic echogenicity with grey-level histogram width: a clinical tissue characterization. Ultrasound Med Biol 1998;24:225-34.

8. Mazziotti G, Sorvillo F, Iorio $\mathrm{S}$ et al. Grey-scale analysis allows a quantitative evaluation of thyroid echogenicity in the patiens with Hashimoto's thyroiditis. Clin Endocrinol 2003;59:223-9.

9. Pierro L, Zaganelli E, Tavola A, Muraglia M. Extraocular muscle size comparison between normal and myopic eyes using standardized A scan echography. Ophthalmologica 1998;212(suppl 1):22-4. 
10. Ossoinig K. Ein neues Gerät für die klinische Echo-Opthalmographie. In $\mathbf{M}$ Masin and J. Poujol (Eds.) Diagnostica Ultrasonica in Ophthalmologia. Paris: Proceedings of SIDUO IV, 1971:131-7.

11. Ossoinig KC. A new echographic sign for the reliable diagnosis of Graves's disease (in German). Klin Monatsbl Augenheilkd 1982;180:189-97.

12. Sacca S, Polizzi A, Macri A, Patrone G, Rolando M. Echographic study of extraocular muscle thickness in children and adults. Eye 2000;14:765-9.

MUDr. Zuzana Hlinomazová, Ph.D., Kř́dlovická 16a, 60300 Brno,

Czech Republic.

e-mail: zhlinom@fnbrno.cz 